\title{
THE PRO-CYCLICALITY OF LOAN LOSS PROVISIONS: EVIDENCE FROM SELECTED EAST ASIAN COUNTRIES
}

\author{
AZIRA ABDUL ADZIS \\ Department of Banking and Risk Management \\ School of Economics, Finance and Banking \\ Universiti Utara Malaysia
}

\begin{abstract}
This study investigated the evidence of pro-cyclical behaviour of loan loss provision in four East Asian countries, namely Malaysia, Thailand, Singapore, and Hong Kong for the period 1995-2009. Pro-cyclical is defined as building up more loan loss provision during the bad times and reducing them in good times. This study hypothesized that pro-cyclical behaviour of loan loss provision exists in East Asian countries, since they had experienced two types of financial crises - Asian financial crisis in 1997 and global economic crisis in 2008. Utilising a sample of 47 banks, the findings demonstrated that there is evidence of a pro-cyclical pattern in the countries studied, as shown by the negative relationship between loan loss provision and GDP. This study does have a policy implication, where bank regulators should take pro-active action in addressing the issue of pro-cyclicality of loan loss provision because in bad times, increasing loan loss provision would affect the bank's profit, weaken the bank's capital, and in turn, diminish its lending activities to creditworthy borrowers.
\end{abstract}

Keywords: Pro-cyclical, Loan loss provision, Malaysian bank

Received: 03/03/2017 Revise: 17/04/2017 Accepted: 17/4/2017 Publish: 27/7/2017

\section{Introduction}

Loan loss provision ${ }^{1}$ are accrual expenses for loan losses and charged on the bank's income statement as a non-cash expense to absorb any losses arising from loan default by customers. Loan loss provision

\footnotetext{
1 Some banks use other terms, such as provision for doubtful debts or charge for bad and doubtful debts, impairment loss, impairment expense, or impairment charge on loans.
} 
generally have a direct impact on banks' earnings and regulatory capital that would affect the shareholders' returns (Ahmed et al., 1999; Bouvatier \& Lepetit, 2008; Hasan \& Wall, 2004). Since these future losses cannot be estimated with certainty, bank managers generally have substantial discretion in setting this provision because of private information, where bank managers know more about loan quality compared to outsiders (Beattie et al., 1995; Wahlen, 1994). In addition, some argued that lack of definitive standards in recognising loan losses under the Generally Accepted Accounting Principles (GAAP) (Beaver \& Engel, 1996; Hasan \& Wall, 2004) has given substantial leeway to bank managers to determine the provision for loan losses.

Previous literature demonstrated that bank loan loss provisioning is associated with issues of income smoothing ${ }^{2}$, capital management ${ }^{3}$, signalling mechanism ${ }^{4}$, and pro-cyclical ${ }^{5}$ behaviour. Among these issues, the pro-cyclical issue has motivated this paper to investigate further since pro-cyclicality is commonly associated with economic condition. This is because loan quality generally moves up and down with the economic cycle. Bikker and $\mathrm{Hu}$ (2002), Laeven and Majnoni (2003), Bikker and Metzemakers (2005), Beatty and Liao (2011), Frait and Komarkova (2013), Skala (2015), Olszak et al., (2016), and Soedarmono et al., (2017) have proven in their research findings that behaviour of loan loss provision is pro-cyclical in the sense that banks tend to lower their provision during economic booms and build up more provision during downturns. In bad times, an increase in loan loss provision would give an effect on the bank's profit. This then could weaken the bank's capital, in turn diminishes its lending activities to creditworthy borrowers, and eventually triggers a credit crunch that might worsen the economic depression (Wall \& Koch, 2000).

The existing literature however, mainly focuses on banks in

2 Income smoothing is manipulating accounting elements in order to achieve target earnings. Specifically in the banking industry, this occurs when bank managers preferably allocate higher provision in the good years to back up the losses that normally happen in the bad years.

3 Banks with low capital may manipulate loan provisioning to meet capital requirements imposed by the bank regulator.

4 Bank managers tend to increase loan loss provision to signal good news to investors as an increase in loan loss provision implies that bank can deal with its problematic loans prudently.

5 Banks may reduce provision during good times and increase the provision during bad times. In bad times, an increase in loan loss provision could weaken a bank's capital and force it to cut loan supply. This phenomenon could prompt a credit crunch and worsen the economic recession. 
European countries and very limited studies investigated the procyclical behaviour of loan loss provision in the context of East Asian economies. Malaysia, Thailand, Singapore, and Hong Kong ${ }^{6}$ were all hit by the Asian financial crisis in 1997 and global economic crisis in 2008. Of the four countries, Thailand was the hardest hit by the 1997 crisis, followed by Malaysia, and the less affected were Singapore and Hong Kong. Malaysia and Thailand were included into the sample because they experienced rapid economic growth during 19911996 (before the 1997 crisis), while Singapore and Hong Kong were regarded as the "Asian Tigers" or commonly referred to as the "Asian Miracle". Radelet and Sachs (1998) highlighted that bank lending in Thailand and Malaysia expanded rapidly before the 1997 crisis where banking claims on the private sector reached 140 percent of GDP in 1996. On the other aspect, Senhadji and Collyns (2002) documented that banks in Thailand, Malaysia, Singapore, and Hong Kong were highly exposed to property sector lending during the 1997 crisis, reaching over 30 percent of total bank loans.

Thus, it is interesting to examine whether loan loss provision in those countries exhibit a significant pro-cyclical pattern as the rapid loan growth during the crisis periods might force banks to set aside more loan loss provision to absorb loan defaults.

\section{Literature Review}

Previous studies described the behaviour of bank loan loss provisioning as pro-cyclical since banks usually build up more loan loss provision during the bad times and lower them during good times. This is because in an expansionary period, there is an expectation that few loans will default and banks reduce their level of loan loss estimation. As a result, banks tend to increase the expected loan losses during recessions because generally, during those times, loan defaults are usually high.

According to Berger and Udell (2004), there are two stylised facts of pro-cyclicality, 1) banks increase their loan disbursement during economic booms and reduce the loan disbursement during economic downturns, which may eventually elicit a credit crunch; and 2) banks set low past due, low non-accrual, low provision, and low chargeoffs during economic growth, increase them slowly during and at

6 Hong Kong is not a country; it is a Special Administrative Region (SAR) of Republic of China. For simplicity, the word country is used. Hong Kong is unique as it has full autonomy in all areas of administration (including possessing its own currency) except defense and foreign affairs. 
the end of growth, and increase them rapidly during the recession. Berger and Udell (2004) stressed that the issue of pro-cyclicality of loan loss provisioning should be addressed prudentially as it could prompt systemic risk. Because of this, several empirical studies have been carried out to address the issue of pro-cyclicality of loan loss provisioning of the banking system.

Cavallo and Majnoni (2002) explored the effect of the lack of regulation in loan loss provisioning practices that may amplify the pro-cyclicality of bank capital. They conjectured that an inadequate loan loss reserve because of weak regulation of loan loss provision could have an effect on bank capital. The shortage of a bank's capital will contract bank lending activities, which could lead to a credit crunch that may worsen economic downturns. Using a sample of $36^{7}$ countries in the period from 1988-1999, the results showed that the level of institutional development significantly affects loan loss provisioning practices across countries. Their findings also suggested that sound provisioning practices should be integrated as a component of capital regulation to help reduce the pro-cyclical effects on bank capital.

Bikker and $\mathrm{Hu}$ (2002) studied the pro-cyclical behaviour of OECD banks under the Basel I regime, using time series data between 1979 and 1999. Specifically, the authors investigated the effect of business cycle on bank profits, loan loss provisioning, and bank lending of OECD countries, including Australia and New Zealand. The findings indicated that profits follow the pattern of business cycles: they increase during economic booms and decrease during economic downturns. In addition, loan loss provision is high during economic downturns, which supports the evidence of pro-cyclicality, but they lessen if the bank net income is relatively high. Finally, the lending behaviour also follows the economic pattern but, surprisingly, the behaviour is driven by demand factors, not supply factors as perceived by bank lending channel theory.

Laeven and Majnoni (2003) further analysed the cyclical patterns of bank loan loss provision as a component of bank capital regulation. Emphasising the issue of the pro-cyclical effect of risk-based bank minimum capital requirements on the economy, Laeven and Majnoni investigated the income smoothing behaviour of banks across

\footnotetext{
7 This includes Australia, New Zealand, Hong Kong, Thailand, Malaysia, and Singapore (classified as non-G10 countries).

8 This stands for Organisation for Economic Co-operation and Development.
} 
the globe ${ }^{9}$ and its affiliation with the economic cycle. The results demonstrated that, on average, banks around the world increase loan loss provisioning during economic downturns and reduce their provisioning during economic expansions. This supports the evidence of pro-cyclical behaviour of loan loss provision. In addition, the authors stressed that the Basel Committee's efforts to standardise capital regulations around the world might be worthless if they do not address the issue of different provisioning practices of banks around the world.

Berger and Udell (2004) employed individual US bank data over the period 1980-2000 to investigate the link between the institutional memory hypothesis and the pro-cyclicality of bank lending behaviour. Their study addressed the issue of weaknesses of bank credit officers to recognise potential loan problems by lessening the credit standard rules during expansions, thus eventually causing a cyclical pattern of business lending during recessions. Focusing on commercial and industrial lending and commercial real estate lending patterns, the results indicated that the two types of loans increase as time passes since the banks' last loan default problem. This supports the theory of pro-cyclicality where bank managers tend to loosen their lending standards and the monitoring of problem loans several years after a recession. In relation to this, Berger and Udell (2004) suggested that bank supervisors should impose stringent rules to make the lending pattern of banks more countercyclical.

Bikker and Metzemakers (2005) extended the studies done by Cavallo and Majnoni (2002), and Laeven and Majnoni (2003). Similar to the previous studies, Bikker and Metzemakers examined the relationship between bank provisioning behaviour and the business cycle. Employing data from OECD countries, the study supported the procyclical theory of bank loan provisioning whereby banks increase loan loss provision during economic downturns and cut loan provisioning during economic booms.

Then, Handorf and Zhu (2006) examined the pro-cyclicality of loan loss provisioning of US banks over the period 1990-1999. Their findings, however, did not support the evidence of pro-cyclical behaviour of loan loss provisioning for average-sized banks, which may also indicate that these banks engage in income smoothing activities that lead to the countercyclical pattern. Nonetheless, the

9 This includes Australia, Malaysia, New Zealand, Singapore, and Thailand. 
existence of pro-cyclicality was found among smaller banks and the largest banks in the US.

Meanwhile on a different continent, Bouvatier and Lepetit (2008) tested the impact of non-discretionary and discretionary components of loan loss provision on European banks' lending activities, particularly from the aspect of credit fluctuations for the period 1992-2000. The findings demonstrated that the non-discretionary component of loan loss provision has a significant relationship with the business cycle. However, the non-discretionary component has no significant relationship with credit fluctuations. The authors strongly supported the implementation of dynamic provisioning, as is applied in Spain, since it promotes a forward-looking approach and hence, reduces the pro-cyclical behaviour of loan loss provision.

Later, a study by Beatty and Liao (2011) exploited the capital crunch theory to examine whether the incurred loss model of loan loss provision has a significant impact on the pro-cyclicality of bank lending for the period 1993-2009. Covering the period after the implementation of the 1988 Basel Risk Based Capital Regulation and the Federal Depository Insurance Corporation Improvement Act of 1991 (FDICIA) in the United States, their findings confirmed the capital crunch theory where there is a strong connection between lending and risk-based capital ratios during depressions. In addition, the results also supported the pro-cyclical hypothesis as banks that delay expected loss recognition would reduce their lending activities more than that of banks that delay less, particularly during recessions.

To address the pro-cyclicality issue, Bouvatier and Lepetit (2012) developed a model to evaluate how provisioning rules influence loan market fluctuations by looking at the effects of loan loss provision on the loan market. Their model compares banks' behaviour in the loan market in three types of provisioning systems: the backwardlooking provisioning system ${ }^{10}$, forward-looking provisioning system $^{11}$, and capital buffer system ${ }^{12}$. The findings concluded that the backward-looking provisioning system magnifies the pro-cyclicality of loan market fluctuations. In light of this, Bouvatier and Lepetit (2012) supported the recommendation by the Basel Committee to implement a forward-looking provisioning system to deal with the

10 Loan loss provision is triggered by past due payments.

11 Loan loss provision comprises two components: one related to past due payments and another related to expected losses.

12 Banks apply backward-provisioning rules and uses a capital buffer to cover expected losses that are not covered by loan loss provision. 
pro-cyclicality issue.

Meanwhile, employing banks from selected European countries including Czech Republic, Frait and Komarkova (2013) analysed the cyclical behaviour of bank loans and loan loss provisioning, and examined to what extent the regulatory and accounting frameworks contribute to it. Similar to Bikker and Metzemakers (2005), the findings indicated that loan loss provisioning of European banks behave procyclically.

Skala (2015) supported Frait and Komarkova (2013) where the findings suggested that Central European banks' reserve-making behaviour is pro-cyclical with respect to national business cycles. Similar to Bouvatier and Lepetit (2008), the author recommended the dynamic provisioning system to reduce the pro-cyclicality of loan loss provision.

Agénor and Zilberman (2015) examined the interaction between loanloss provision and business cycles in a dynamic stochastic general equilibrium model with credit market imperfections. The findings suggested that the forward-looking loan-loss provisioning regime can be highly effective in mitigating pro-cyclicality of the financial system.

Using a panel data of 3000 banks operating in the European Union in 1996-2011, Olszak et al., (2016) found that loan loss provision in large, publicly-traded, and commercial banks, as well as in banks reporting consolidated statements, are more pro-cyclical. The study supported the view that micro-prudential supervision is not sufficient to combat the pro-cyclicality of the banking sector, and therefore should be supplemented with macro-prudential supervision.

Different from other studies, Soedarmono et al. (2017) examined the pro-cyclicality of loan loss provision in the context of Islamic banks. Employing a sample of 146 Islamic banks around the world that covered period from 1997 to 2012, the findings indicated that loan loss provisioning in Islamic banks is also pro-cyclical, where higher economic growth leads to a decline in loan loss provision. The study advocated the importance of strengthening discretionary behaviour in Islamic banks in terms of capital management to offset the procyclicality of loan loss provision.

In summary, the majority of previous literature concluded that bank loan loss provisioning behaviour is highly cyclical where banks tend to increase loan loss provision during the economic downturns. Previous literature however, focused more on European banks and 
little attention was given to banks in East Asian economies. Thus, this paper hypothesises that:

H1 Pro-cyclical behaviour of loan loss provision exists in banks of East Asian countries for the period 1995-2009.

\section{Methodology}

\section{Sample and Data}

A sample of commercial banks from countries in East Asia was utilised-Hong Kong, Singapore, Malaysia, and Thailand. These countries provided a good avenue to study the pro-cyclical pattern as they experienced two types of economic downturns, namely the 1997 financial crisis and 2008 global financial crisis. This study employed unbalanced panel data extracted from consolidated income statements and balance sheets of the commercial bank sample. Only commercial banks were selected in order to get homogeneous data (Bikker \& Metzemakers, 2005, p. 148) as well as to maintain consistency across countries (Kwan, 2003, p. 474). Panel data on the other aspect, provides several advantages in this study as it could control for the unobserved bank-specific effects, control for time-invariant variables, and possibly reduce the problem of multicollinearity among variables (Baltagi, 2008). Bank financial data were collected from Bankscope database for the period 1995-2009. This period covered two important crises which were the 1997 financial crisis and 2008 global financial crisis. Macroeconomic data were obtained from World Development Indicator, World Bank. Table 1 shows a selection of sample banks for this study. Table 2 lists the name of selected banks in each country.

Table 1

Sample selection

\begin{tabular}{lccc}
\hline $\begin{array}{c}\text { Country/ } \\
\text { Region }\end{array}$ & $\begin{array}{c}\text { No. of locally } \\
\text { incorporated } \\
\text { commercial } \\
\text { banks in } \\
\text { Bankscope } \\
\text { database: }\end{array}$ & $\begin{array}{c}\text { Less: Number } \\
\text { of locally } \\
\text { incorporated } \\
\text { commercial } \\
\text { banks dropped } \\
\text { from the sample }\end{array}$ & $\begin{array}{c}\text { FINAL } \\
\text { SAMPLE }\end{array}$ \\
\hline Malaysia & 20 & 3 & 17 \\
Singapore & 5 & 2 & 3 \\
Thailand & 14 & 0 & 14 \\
Hong Kong & 22 & 9 & 13
\end{tabular}


IJMS 24 (1), 23-39 (2017)

TOTAL

61

14

47

Source: Bankscope database

Table 2

List of banks in each country

(continued) 
IJMS 24 (1), 23-39 (2017)

\begin{tabular}{|c|c|c|c|c|c|c|c|}
\hline \multicolumn{8}{|c|}{ Country } \\
\hline \multicolumn{2}{|r|}{ Malaysia } & \multicolumn{2}{|r|}{ Singapore } & \multicolumn{2}{|r|}{ Thailand } & \multicolumn{2}{|r|}{ Hong Kong } \\
\hline \multirow[t]{2}{*}{1.} & Affin Bank & 1. & Far Eastern & 1. & ACL Bank & 1. & Bank of East \\
\hline & Berhad & & Bank Limited & & Public Company & & Asia Limited \\
\hline \multirow[t]{4}{*}{2.} & Alliance & 2. & Oversea- & & Limited & 2. & Chiyu \\
\hline & Bank & & Chinese & 2. & Bangkok Bank & & Banking \\
\hline & Malaysia & & Banking & & Public Company & & Corporation \\
\hline & Berhad & & Corporation & & Limited & 3. & Chong Hing \\
\hline \multirow[t]{2}{*}{3.} & AmBank & & Limited & 3. & Bank of & & Bank Limited \\
\hline & (M) Berhad & 3. & United & & Ayudhya Public & 4. & Citic Bank \\
\hline \multirow[t]{3}{*}{4.} & Bangkok & & Overseas & & Company & & International \\
\hline & Bank & & Bank Limited & & Limited & & Limited \\
\hline & Berhad & & & 4. & CIMB Thai Bank & 5. & Dah Sing Bank \\
\hline \multirow[t]{2}{*}{5.} & Bank of & & & & Public Company & 6. & Fubon Bank \\
\hline & Nova Scotia & & & & Limited & 7. & Hang Seng \\
\hline \multirow[t]{2}{*}{6.} & CIMB Bank & & & 5. & Kasikornbank & & Bank \\
\hline & Berhad & & & & Public Company & 8. & Hong Kong \\
\hline \multirow[t]{2}{*}{7.} & Citibank & & & & Limited & & and Shanghai \\
\hline & Berhad & & & 6. & Kiatnakin Bank & & Banking \\
\hline \multirow[t]{4}{*}{8.} & Deutsche & & & & Public Company & & Corporation \\
\hline & Bank & & & & Limited & 9. & Industrial and \\
\hline & (Malaysia) & & & 7. & Krung Thai & & Commercial \\
\hline & Berhad & & & & Bank Public & & Bank \\
\hline \multirow[t]{2}{*}{9.} & EON Bank & & & & Company & 10. & Nanyang \\
\hline & Berhad & & & & Limited & & Commercial \\
\hline \multirow[t]{3}{*}{10.} & Hong & & & 8. & Siam City Bank & & Bank \\
\hline & Leong Bank & & & & Public Company & 11. & Public Bank \\
\hline & Berhad & & & & Limited & & (HK) Limited \\
\hline \multirow[t]{3}{*}{11.} & HSBC Bank & & & 9. & Siam & 12. & Shanghai \\
\hline & Malaysia & & & & Commercial & & Commercial \\
\hline & Berhad & & & & Bank Public & & Bank Limited \\
\hline \multirow[t]{3}{*}{12.} & Malayan & & & & Company & 13. & Wing Lung \\
\hline & Banking & & & & Limited & & Bank \\
\hline & Berhad & & & 10. & Thanachart & & \\
\hline \multirow[t]{3}{*}{13.} & OCBC Bank & & & & Bank Public & & \\
\hline & (Malaysia) & & & & Company & & \\
\hline & Berhad & & & & Limited & & \\
\hline \multirow[t]{2}{*}{14.} & Public Bank & & & 11. & Tisco Bank & & \\
\hline & Berhad & & & & Public Company & & \\
\hline \multirow[t]{2}{*}{15.} & RHB Bank & & & & Limited & & \\
\hline & Berhad & & & 12. & TMB Bank & & \\
\hline \multirow[t]{3}{*}{16.} & Royal Bank & & & & Public Company & & \\
\hline & of Scotland & & & & Limited & & \\
\hline & Berhad & & & & & & \\
\hline
\end{tabular}


IJMS 24 (1), 23-39 (2017)

\begin{tabular}{|c|c|c|c|c|c|}
\hline \multicolumn{6}{|c|}{ Country } \\
\hline & Malaysia & Singapore & & Thailand & Hong Kong \\
\hline \multirow[t]{3}{*}{17.} & Southern & & 13. & Standard & \\
\hline & Bank & & & Chartered Bank & \\
\hline & Berhad & & & (Thai) Public & \\
\hline \multirow[t]{5}{*}{18.} & Standard & & & Company & \\
\hline & Chartered & & & Limited & \\
\hline & Bank & & 14. & United Overseas & \\
\hline & Malaysia & & & Bank (Thai) PCL & \\
\hline & Berhad & & & & \\
\hline \multirow[t]{5}{*}{19.} & United & & & & \\
\hline & Overseas & & & & \\
\hline & Bank & & & & \\
\hline & (Malaysia) & & & & \\
\hline & Berhad & & & & \\
\hline
\end{tabular}

Source: Bankscope database

\section{Model}

To investigate the evidence of pro-cyclical behaviour of bank loan loss provision, this study used a modified model based on Laeven and Majnoni (2003), and Fonseca and Gonzalez (2008). The basic regression model is as follows:

$\mathrm{LLP}_{i t}=\beta_{0}+\beta_{1} \mathrm{GDPGR}_{t}+\beta_{2} \Delta \mathrm{LOAN}_{i t}+\beta_{3} \mathrm{BLLA}_{i t}+\beta_{4} \mathrm{LOAN} \mathrm{TA}_{i t}+\beta_{5} \mathrm{SIZE}+\epsilon_{i t}$

where:

GDPGR $_{t}=$ the annual growth of real per capita GDP at year $t$. According to Guenther and Young (2000, p. 64) economic growth rate (GDP) is the best proxy for the type of underlying economic activity compared to other real economic activity such as unemployment rate and money market interest rate. The relationship between GDP growth and LLP will test the evidence of pro-cyclical behaviour of the sample. A negative relationship implies that banks increase their loan loss provision when business cycle falls, which will prove the evidence of pro-cyclical behaviour in the sample (Bikker \& Metzemakers, 2005).

$\Delta \mathbf{L O A N}_{i t}=$ Change in total loans outstanding for bank $i$ and year $t$. This variable is used to control for default risk (Wahlen, 1994). A positive coefficient is expected, as loan loss provision will increase when total loans increase due to the potentially higher default risk. However, for imprudent banks, the association between loan growth and loan loss provision will be negative, as they tend to lower the monitoring of their loans quality especially when experiencing sudden loan growth in economic expansion. 
BLLA $_{i t}=$ beginning loan loss allowance of bank $i$ at year $t$ / average total assets. This nondiscretionary variable captures prior provision as well as controlling for default risk. A negative coefficient is expected, as according to Wahlen (1994), and Lobo and Yang (2001), BLLA has a negative association with LLP.

LOAN/TA ${ }_{i t}=$ total loans divided by total assets of bank $i$ at year $t$. It acts as a proxy for credit risk of bank's loan portfolio. Generally, the provision amount is determined based on loan portfolio quality. The rise in loans portfolio will force the bank to increase its loan loss provision as the higher the default risk, the larger the provision would be. So, the coefficient is expected to be positive.

SIZE $_{i t}=$ Bank size may influence the pro-cyclical behaviour of loan loss provision, and it is measured by the natural logarithm of total assets of bank $i$ in year $t$.

\section{Results and Discussion}

\section{Descriptive statistic}

Table 3

Descriptive statistics of key variables

\begin{tabular}{lcccccc}
\hline & \multicolumn{6}{c}{ Variable } \\
& LLP & GDP & $\Delta$ LOANS & BLLA & LOANTA & SIZE \\
\hline Mean & 0.0059 & 4.1328 & 0.0610 & 0.0316 & 0.5911 & 24.80 \\
Median & 0.0037 & 5.3250 & 0.0460 & 0.0199 & 0.6068 & 24.69 \\
Maximum & 0.0684 & 11.7000 & 1.3481 & 0.6797 & 1.1122 & 29.10 \\
Minimum & -0.0425 & -10.5000 & -0.4555 & 0.0015 & 0.0572 & 19.65 \\
Std. Dev. & 0.0087 & 4.3887 & 0.1267 & 0.0492 & 0.1540 & 1.70 \\
Observations & 636 & 740 & 664 & 600 & 694 & 664 \\
\hline
\end{tabular}

Table 3 provides descriptive statistics of the variables used in this study. The average of loan loss provision for the sample was $0.59 \%$, GDP growth rate's average was $4.13 \%$, loan growth rate on average 
was $6.1 \%$, beginning loan loss allowance had a mean of $3.16 \%$, and the average of loans to total assets ratio was $59.11 \%$ (more than half of the total assets). The average bank size in the sample was 24.8.

\section{Pro-cyclicality test}

Table 5

Test of pro-cyclicality: Aggregate data

\begin{tabular}{lcc}
\hline Independent variables & \multicolumn{2}{c}{ Dependent variable: Loan Loss Provision } \\
\cline { 2 - 3 } & $\begin{array}{c}\text { Predicted } \\
\text { sign }\end{array}$ & Pro-cyclical model \\
\hline Intercept & $?$ & -0.0262 \\
& & $(-0.6773)$ \\
GDP & - & $-0.0007^{* * *}$ \\
& & $(-3.8296)$ \\
L LOANS & $?$ & $-0.0057^{*}$ \\
& & $(-1.7071)$ \\
BLLA & - & $-0.0581^{* * *}$ \\
& & $(-3.3938)$ \\
LOANTA & + & $0.0082^{*}$ \\
& & $(1.8977)$ \\
SIZE & $?$ & 0.0013 \\
& & $(0.8482)$ \\
Year dummies & & Yes \\
Bank dummies & & Yes \\
Adjusted R-Squared & & 0.44 \\
F-statistic & & $8.0215^{* * *}$ \\
No. of Observations & & 575 \\
No. of Banks & & 47 \\
\hline
\end{tabular}

Regressions were estimated using panel least squares for the period 1995 to 2009. White's heteroscedasticity-adjusted $t$-statistics are given in parentheses. ${ }^{* * *}, * *$, and ${ }^{*}$ represent significance at $1 \%, 5 \%$, and $10 \%$ levels, respectively. The highly significant $F$-statistic means that all explanatory variables have joint effect on loan loss provision.

Table 5 reports the results for the aggregate data. The results showed that the variable of interest, GDP growth, is negatively significantindicating that there is evidence of pro-cyclical behaviour in the 
sample. Therefore, holding all other factors constant, on average, banks tend to increase their loan loss provision during economic downturns. The loan growth shows a negative and significant coefficient and this means that on average, banks in the sample lower loan loss provision during periods when loan growth is on the rise. This finding is similar to Cavallo and Majnoni (2002), Laeven and Majnoni (2003), and Beatty and Liao (2011). It might also explain the optimistic behaviour of banks with regard to lending activities, as bankers tend to ease their credit standards during expansion. This, in turn, may lead to lower monitoring efforts and, consequently, banks have a tendency to understate their loan loss provision due to the possibility that the default rates are lower.

Beginning loan loss allowance showed a negative and statistically significant coefficient, demonstrating that the previous year's loan loss allowance determines the current year's loan loss provision for banks in the sample studied. The proxy for the credit risk of a bank's loan portfolio, total loans to total assets (LOANTA), was positively significant, meaning that there is evidence to suggest that the loan portfolio risk determines the loan loss provision for the average banks in the sample studied.

The insignificant coefficient of the SIZE variable suggested that bank size does not explain the way average banks in the sample determine their loan loss provision. Further analysis was done by breaking down the sample by country. Table 6 reports the results.

Table 6

Test of pro-cyclicality: Country analysis

\begin{tabular}{lccccc}
\hline \multirow{2}{*}{$\begin{array}{l}\text { Independent } \\
\text { variables }\end{array}$} & \multicolumn{5}{c}{ Dependent variable: Loan Loss Provision } \\
\cline { 2 - 6 } & $\begin{array}{c}\text { Predicted } \\
\text { sign }\end{array}$ & Malaysia & Thailand & $\begin{array}{l}\text { Hong } \\
\text { Kong }\end{array}$ & Singapore \\
\hline Intercept & $?$ & $0.0901^{* * *}$ & $0.1007^{*}$ & 0.0143 & $0.1484^{* * *}$ \\
& & $(3.8966)$ & $(1.9588)$ & $(0.7818)$ & $(5.2746)$ \\
GDP & - & $-0.0005^{* * *}$ & $-0.0008^{*}$ & & $-0.0004^{* * *}$ \\
& & $(-5.4431)$ & -1.9481 & $-0.0003^{* * *}$ & $(-3.4122)$ \\
& & & & $(-4.3599)$ & \\
\multirow{2}{*}{ LOANS } & + & -0.0050 & -0.0102 & -0.0106 & $-0.0134^{* * *}$ \\
& & $(-1.0541)$ & $(-1.3316)$ & $(-1.5478)$ & $(-3.7575)$
\end{tabular}


IJMS 24 (1), 23-39 (2017)

\begin{tabular}{lccccc}
\hline Independent & \multicolumn{5}{c}{ Dependent variable: Loan Loss Provision } \\
\cline { 2 - 6 } & $\begin{array}{c}\text { Predicted } \\
\text { sign }\end{array}$ & Malaysia & Thailand & $\begin{array}{l}\text { Hong } \\
\text { Kong }\end{array}$ & Singapore \\
\hline BLLA & - & -0.0459 & $-0.0530^{* *}$ & $0.1115^{* *}$ & $-0.1209^{* * *}$ \\
& & $(-1.4477)$ & $(-2.1888)$ & $(2.3691)$ & $(-2.4076)$ \\
\hline LOANTA & + & $0.0109^{* * *}$ & 0.0147 & 0.0076 & $0.0135^{* * *}$ \\
SIZE & $(3.3730)$ & $(1.0599)$ & $(1.3991)$ & $(2.4076)$ \\
Year & $-0.0036^{* * *}$ & $-0.0036^{*}$ & -0.0006 & $-0.0061^{* * *}$ \\
dummies & $(-3.9078)$ & $(-1.7386)$ & $(-0.8870)$ & $(-5.3668)$ \\
$\begin{array}{l}\text { Bank } \\
\text { dummies }\end{array}$ & No & No & No & No \\
$\begin{array}{l}\text { Adjusted } \\
\text { R-Squared }\end{array}$ & & Yes & Yes & Yes & Yes \\
$\begin{array}{l}\text { F-statistic } \\
\text { No. of } \\
\text { observations }\end{array}$ & 0.48 & 0.18 & 0.40 & 0.62 \\
No. of banks & $10.1489^{* * *}$ & $2.7309^{* * *}$ & $8.4436^{* * *}$ & $8.5113^{* * *}$ \\
\hline
\end{tabular}

Regressions were estimated using panel least squares for the period 1995 to 2009. White's heteroscedasticity-adjusted $t$-statistics are given in parentheses. $* * * * *$, and ${ }^{*}$ represent significance at $1 \%, 5 \%$, and $10 \%$ levels, respectively. The highly significant $F$-statistic means that all explanatory variables have joint effect on loan loss provision.

Results in Table 6 further asserted the evidence of pro-cyclical behaviour of loan loss provision in Asian countries, as shown by the negative and significant coefficient of the main variable of interest, GDP, with the LLP.

\section{Conclusion}

This study investigated the pro-cyclical behaviour of loan loss provision among banks in selected East Asian countries for the period 1995-2009. These countries provided a unique avenue to study the pro-cyclical effects as they experienced two types of economic downturns, namely the 1997 financial crisis, and 2008 global financial crisis. The findings suggested that there is evidence of pro-cyclical behaviour in the countries studied. This study does have policy implication, where bank regulators should take pro-active action in addressing the issue of pro-cyclicality of loan loss provision because 
in bad times, increasing loan loss provision would affect a bank's profit, weaken the bank's capital, and in turn, diminish its lending activities to creditworthy borrowers. Eventually, this could trigger a credit crunch that might worsen the economic depressions (Wall \& Koch, 2000). Therefore, it is interesting to pay special attention to the dynamic provisioning ${ }^{13}$ approach practised by the Spanish banking system to counter-cycle the loan provisioning, as the system has proven very useful for Spanish banks during the 2008 global financial crisis (Saurina, 2009, p. 25).

\section{Acknowledgements}

The earlier version of this paper has benefited from feedback and comments from the $15^{\text {th }}$ Malaysian Finance Association Conference 2013 (MFA 2013) at Sime Darby Convention Centre, Bukit Kiara Kuala Lumpur, 2-4 June 2013.

\section{References}

Agénor, P. R., \& Zilberman, R. (2015). Loan loss provisioning rules, procyclicality, and financial volatility. Journal of Banking and Finance, 61, 301-315.

Ahmed, A. S., Takeda, C., \& Thomas, S. (1999). Bank loan loss provision: a reexamination of capital management, earnings management and signalling effects. Journal of Accounting and Economics, 28, 1-25.

Baltagi, B. H. (2008). Econometric analysis of panel data (4th ed.). West Sussex, UK: John Wiley and Sons, Ltd.

Beattie, V. A., Casson, P. D., Dale, R. S., McKenzie, G. W., Sutcliffe, C. M. S., \& Turner, M. J. (1995). Banks and Bad Debts: Accounting for Loan Losses in International Banking. England: John Wiley and Sons.

Beatty, A., \& Liao, S. (2011). Do delays in expected loss recognition affect banks' willingness to lend? Journal of Accounting and Economics, 52(1), 1-20.

Beaver, W. H., \& Engel, E. E. (1996). Discretionary behaviour with respect to allowances for loan losses and the behaviour of security prices. Journal of Accounting and Economics, 22, 177-206.

13 The main concept of dynamic provisioning approach is to counter-cycle loan loss provisioning by encouraging banks to build up provision during the good years, which is to be drawn on in bad years to preserve banks' soundness. 
Berger, A. N., \& Udell, G. F. (2004). The institutional memory hypothesis and the procyclicality of bank lending behaviour. Journal of Financial Intermediation, 13(4), 458-495.

Bikker, J. A., \& Hu, H. (2002). Cyclical patterns in profits, provisioning and lending of banks, DNB Staff Reports, No. 86. Amsterdam: De Nederlandsche Bank.

Bikker, J. A., \& Metzemakers, P. A. J. (2005). Bank provisioning behaviour and procyclicality. Journal of International Financial Markets, Institutions and Money, 15(2), 141-157.

Bouvatier, V., \& Lepetit, L. (2008). Banks' procyclical behaviour: Does provisioning matter? International Financial Markets, Institutions and Money, 18, 513-526.

Bouvatier, V., \& Lepetit, L. (2012). Provisioning rules and bank lending: A theoretical model. Journal of Financial Stability, 8(1), 25-31.

Cavallo, M., \& Majnoni, G. (2002). Do banks provision for bad loans in good times? Empirical evidence and policy implications. In Ratings, rating agencies and the global financial system (pp. 319342). Springer US.

Fonseca, A. R., \& Gonzalez, F. (2008). Cross-country determinants of bank income smoothing by managing loan-loss provision. Journal of Banking and Finance, 32, 217-228.

Frait, J., \& Komarkova, Z. (2013). Loan loss provisioning in selected European banking sectors: do banks really behave in a procyclical way? Finance a Uver, 63(4), 308.

Guenther, D. A., \& Young, D. (2000). The association between financial accounting measures and real economic activity: a multinational study. Journal of Accounting and Economics, 29(1), 53-72.

Hasan, I., \& Wall, L. D. (2004). Determinants of the loan loss allowance: Some cross-country comparisons. The Financial Review, 39, 129152.

Kwan, S. H. (2003). Operating performance of banks among Asian economies: An international and time series comparison. Journal of Banking and Finance, 27, 471-489.

Laeven, L., \& Majnoni, G. (2003). Loan loss provisioning and economic slowdowns: Too much, too late? Journal of Financial Intermediation, 12, 178-197.

Lobo, G. J., \& Yang, D.-H. (2001). Bank managers' heterogeneous decisions on discretionary loan loss provision. Review of Quantitative Finance and Accounting, 16, 223-250. 